\title{
Oncogenic KRAS: Signaling and Drug Resistance
}

\author{
Hyeon Jin Kim ${ }^{1,+} \mathbb{D}$, Han Na Lee ${ }^{1,+} \mathbb{C}$, Mi Suk Jeong ${ }^{2, *}$ and Se Bok Jang ${ }^{1, *}$ \\ 1 Department of Molecular Biology, College of Natural Sciences, Pusan National University, Jangjeon-dong, \\ Geumjeong-gu, Busan 46241, Korea; khjkhj0903@naver.com (H.J.K.); emille96@naver.com (H.N.L.) \\ 2 Institute for Plastic Information and Energy Materials and Sustainable Utilization of Photovoltaic Energy \\ Research Center, Pusan National University, Jangjeon-dong, Geumjeong-gu, Busan 46241, Korea \\ * Correspondence: 123misuk@pusan.ac.kr (M.S.J.); sbjang@pusan.ac.kr (S.B.J.); Tel.: +82-51-510-2523 (S.B.J.); \\ Fax: +82-51-581-2544 (S.B.J.) \\ + Authors contributed equally.
}

check for

updates

Citation: Kim, H.J.; Lee, H.N.; Jeong, M.S.; Jang, S.B. Oncogenic KRAS: Signaling and Drug Resistance. Cancers 2021, 13, 5599. https:// doi.org/10.3390/cancers13225599

Academic Editor: Chiara Ambrogio

Received: 28 September 2021

Accepted: 5 November 2021

Published: 9 November 2021

Publisher's Note: MDPI stays neutral with regard to jurisdictional claims in published maps and institutional affiliations.

Copyright: (c) 2021 by the authors. Licensee MDPI, Basel, Switzerland. This article is an open access article distributed under the terms and conditions of the Creative Commons Attribution (CC BY) license (https:/ / creativecommons.org/licenses/by/ $4.0 /)$.
Simple Summary: KRAS is one of the oncogenic proteins and best well-known GTPase proteins. Although KRAS serves as regulation of cellular process, abnormal mutated and GTP-bound KRAS is highly expressed in human cancers. Understanding biological characteristics and precise signaling of KRAS proteins is essential for targeted cancer therapy. This review explains signal transduction and exploration of targeted anticancer by activated KRAS.

Abstract: RAS proteins play a role in many physiological signals transduction processes, including cell growth, division, and survival. The Ras protein has amino acids 188-189 and functions as GTPase. These proteins are switch molecules that cycle between inactive GDP-bound and active GTP-bound by guanine nucleotide exchange factors (GEFs). KRAS is one of the Ras superfamily isoforms (N-RAS, H-RAS, and K-RAS) that frequently mutate in cancer. The mutation of KRAS is essentially performing the transformation in humans. Since most RAS proteins belong to GTPase, mutated and GTP-bound active RAS is found in many cancers. Despite KRAS being an important molecule in mostly human cancer, including pancreatic and breast, numerous efforts in years past have persisted in cancer therapy targeting KRAS mutant. This review summarizes the biological characteristics of these proteins and the recent progress in the exploration of KRAS-targeted anticancer, leading to new insight.

Keywords: KRAS; GTPase; signaling; mutant; inhibitor; drug resistance

\section{KRAS Protein \\ KRAS Structure, Function}

KRAS is one of the RAS superfamilies or Ras-like GTPase and belongs to the group of small-guanosine triphosphate (GTP) binding proteins. The Ras protein is one of the superfamilies that shares functional small GTPases and is composed of RAS, RHO, RAB, RAC, RAN, and ARF (Figure 1) [1]. The RAS family is divided into six subfamilies (RAS, RAL, RAP, RHEB, RAD, and RIT). The RAS family commonly has a catalytic G domain, which generates GTPase. Also frequently studied in the RAS family are a Harvey-Ras (H-RAS), neuroblastoma-Ras (N-RAS), and two variants of Kristen-RAS (K-RAS). While the first variant KRAS4A is weakly expressed in the human cell, the second variant KRAS4B is excessively expressed [2,3]. KRAS protein contains 188 amino acids, with a molecular mass of $23.2 \mathrm{kDa}$, and is performed as the first sensor of intracellular signaling pathway $[2,4]$. Activation of KRAS is regulated by the on-off switch, resulting in an intracellular effector pathway. The 'on' and 'off' conformation is proceeded by binding of GTP and GDP (Figure 2). Under physiological conditions, the transition between GDP and GTP is involved in GEF by promoting GDP for GTP exchange and GAP by accelerating RASmediated GTP hydrolysis [2,5]. KRAS protein-bounded GTP is undergoing conformation 
change at two regions. The first region (amino acids 30-38) and the second region (amino acids 59-67) form an effector loop, controlling the binding of GTPase to effector molecules. Once conformational change occurs, the effector molecules of GTP activity, such as GTPaseactivating proteins (GAPs) and guanine-exchange/releasing factors (GEFs/GRFs), affect the interaction [2]. The GAPs are able to amplify the GTPase activity of KRAS protein 100,000-fold more than RAS protein-bounded GDP [6]. Contrariwise to activation of GTP activity, the GEFs/GRFs reduce GTPase activity by promoting the release of GTP [2]. Thus, the mutation of KRAS protein impairs GTPase activity, which is mainly found in the oncogene RAS form. The mutation of RAS p21 tends to rapidly exchange GDP for GTP, which induces an active form of RAS. An aberrant form of KRAS protein affects the effector that is related to the important cellular pathway. Accordingly, hyperactivation of RAS signaling is related to cancer and human disease such as RASopathies [7].

\begin{tabular}{|c|c|c|c|c|c|}
\hline & & & RAS & & \\
\hline & Ras & Rho & Rab & Arf & Ran \\
\hline Member & $\begin{array}{l}\text { Rap, R-Ras, } \\
\text { Ral, Rheb }\end{array}$ & $\begin{array}{l}\text { RhoA, Rac1, } \\
\text { Cdc42 }\end{array}$ & Rab5, Rab25 & Arf1, Arf5 & Ran \\
\hline Function & $\begin{array}{l}\text { Regulation of } \\
\text { cytoplasmic } \\
\text { signaling by } \\
\text { extracellular } \\
\text { stimulation; } \\
\text { control gene } \\
\text { expression and } \\
\text { regulation of cell } \\
\text { proliferation, and } \\
\text { survival }\end{array}$ & $\begin{array}{l}\text { Regulation of actin } \\
\text { organization, cell } \\
\text { cycle progression, } \\
\text { and gene } \\
\text { expression }\end{array}$ & $\begin{array}{l}\text { Regu } \\
\text { intrac } \\
\text { vesic } \\
\text { transp } \\
\text { traffic } \\
\text { protei } \\
\text { contrc } \\
\text { prolife }\end{array}$ & $\begin{array}{l}\text { ation of } \\
\text { ellular } \\
\text { llar } \\
\text { ort and } \\
\text { king of } \\
\text { i } \\
\text { I cell } \\
\text { ration }\end{array}$ & $\begin{array}{l}\text { Regulation of } \\
\text { nucleocytoplasmic } \\
\text { transport of both } \\
\text { RNA and proteins; } \\
\text { control cell cycle } \\
\text { progression }\end{array}$ \\
\hline
\end{tabular}

Figure 1. The branched tree of RAS superfamily. RAS superfamily comprises 150 human members and is divided into five different major branches. The Ras sarcoma (Ras) family comprises 36 members and has been the subject of intense research. The Ras homologous (Rho) family comprises 20 members, RhoA, Rac1, and Cdc42 being the best studied. The Ras-like proteins in brain (Rab), the largest branches of the superfamily, comprise 61 members. The ADP-ribosylation factor (Arf) family comprises 27 members; Rab and Arf families have similar functions. The Ras-like nuclear (Ran) family presents only one member $[1,8]$.

RAS has three domains (Figure 3). RAS isoforms share G-domain that highly sequences homology (90\%). The G-domain (residues 1-166) consists of an effector lobe (residues 1-86) and an allosteric lobe (87-166). This domain is composed of the six betastrands and is surrounded by five alpha-helices [9]. KRAS has hypervariable regions (HVRs) present in the C-terminal element. The HVRs region undergoes a post-translational modification (PTM), including by farnesylation, palmitoylation, methylation, phosphorylation, nitrosylation, and ubiquitination [10]. Particularly, the carboxyl terminal PTMs are related to affinity for membrane and trafficking with cellular compartments. According to research, palmitoylated HRAS is located in the plasma membrane, but depalmitoylated HRAS is accumulated in the ER and Golgi [11]. The HVRs play a role in anchoring RAS to the membrane, which displays among Ras proteins less than $15 \%$ of sequence homology [12]. The effector lobe mainly interacts with RAS effectors such as rapidly accelerated fibrosarcoma (RAF), PI3K, and RalGEF. The allosteric lobe plays a role in intra-protein communication, which connects the effector lobe to membrane-interacting residues $[13,14]$. The effector lobe is divided into two switch regions, switch-I (residues 30-38) and switch-II (residues 59-76), controlling the specificity of the binding to effector molecule and affecting interaction of transducer to cellular downstream [2,7]. Different from the Ras protein, the effector lobe of KRAS additionally has P-loop-phosphate binding loops (residues 10-16 
and 56-59), which indicate a GTP-binding pocket. These play a role in interacting with the b-phosphate and c-phosphate of GTP [2]. Moreover, residues 116-119 and 152-165 interact with the guanine base. In the case of binding of GTP with P-loop-phosphate, GTP temporarily binds to Ras protein. Additionally, KRAS protein has a CAXX motif, which is related to plasma membrane localization. The KRAS protein should localize plasma membrane to regulate signal transduction. For the plasma membrane localization, KRAS protein is needed for farnesylation in the cysteine residue of CAXX ( $C$ represents cysteine, $A$ is an aliphatic amino acid, and $X$ is any amino acid) motif $[15,16]$. After farnesylation of cysteine residues in the CAXX, the AXX amino acid is cleaved by protease, followed by the methylation the free carboxyl group of the cysteine, and these events occur on the cytosolic surface of the endoplasmic reticulum [16]. Additionally, in the case of the splice variant KRAS4A, the AXX motif is palmitoylated by palmitoyl transferase and targeted to the membrane. However, in the case of the splice variant KRAS4B, it is speculated that membrane localization occurs through a microtubule-dependent mechanism [17].

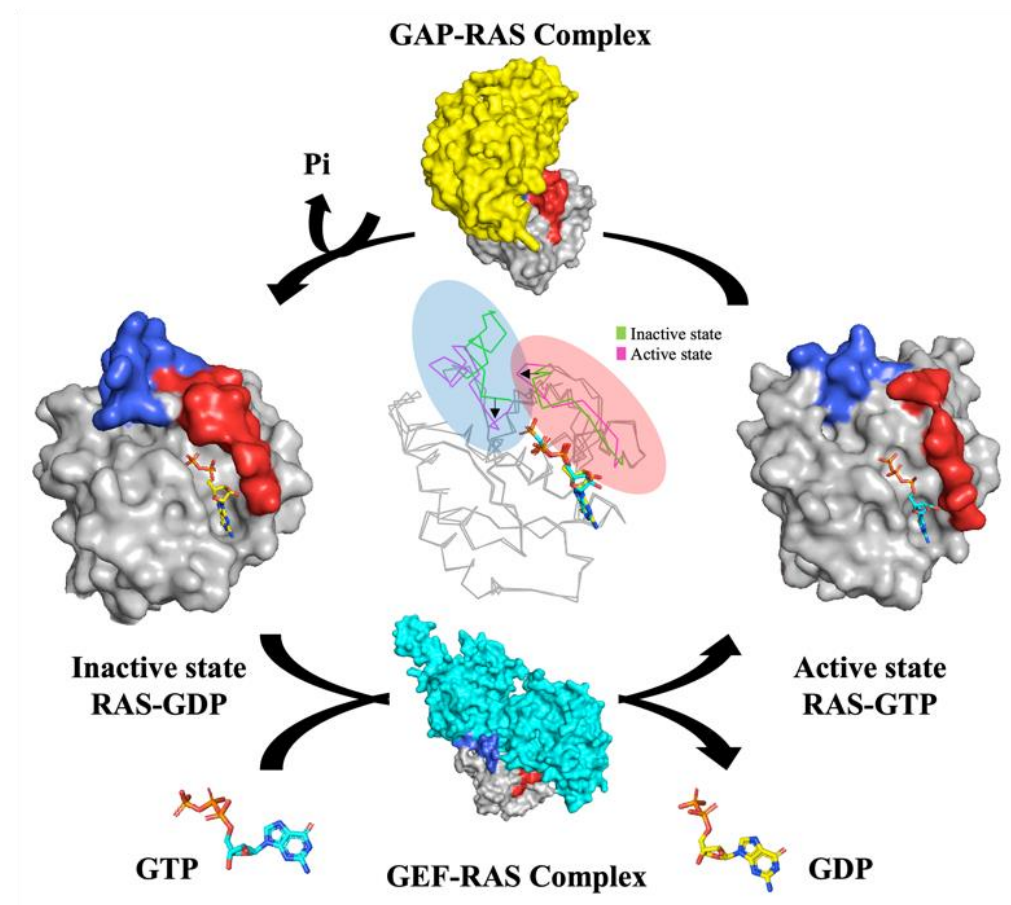

Figure 2. RAS cycles between 'inactive' state bound to GDP and 'active' state bound to GTP. RAS acts as a guanosine diphosphate (GDP)-inactive molecular switch in resting cells and becomes activated in response to extracellular receptors by binding guanosine triphosphate (GTP), as catalyzed by the guanine nucleotide exchange factor (GEF). The GTPase-activating protein (GAP) stops the Ras signaling by switching Ras into an inactive GDP-bound signaling state. PDB IDs: 7C40 (RAS-GDP), 6Q21 (RAS-GTP), 1WQ1 (GAP-RAS), and 4G0N (GEF-RAS).

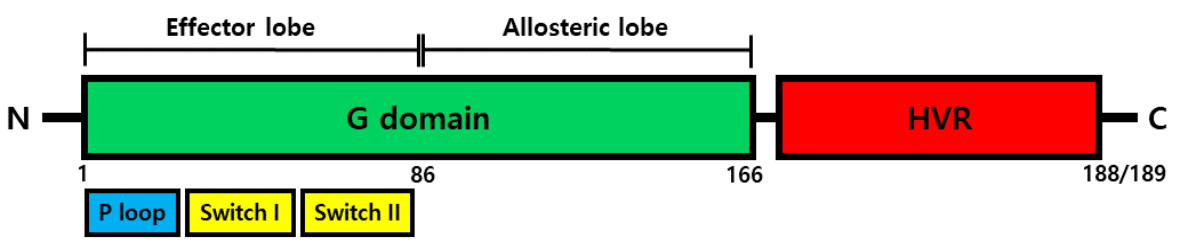

Figure 3. Structure analysis of KRAS. Schematic representation of the full-length KRAS isoform domain. KRAS consists of G domain (residue 1-166) and hypervariable region (HVR, residue 167-188/189). G domain is divided into effector lobe (residue 1-86) and allosteric lobe (residue 87-166). In addition, effector lobe consists of P-loop-phosphate binding loops (residue 10-16), Switch I (residue 30-38), and Switch II (residue 59-76). 


\section{KRAS Signaling}

In the cell membrane, KRAS undergoes inactive state by binding of guanosine diphosphate (GDP) and active state by binding of guanosine triphosphate (GTP). KRAS protein is normally maintained in oncogenesis, but mutated KRAS is decreased in interactions with GTPase activator protein [18]. Moreover, the mutated KRAS tends to prefer binding with GTP than GDP. The activation form of GTP-bound Ras protein influences the activation downstream effector even in the absence of growth factor [19]. Typically, the Ras signal pathway is activated by the protein tyrosine kinase receptor. The epidermal growth factor receptor (EGFR) and the platelet-derived growth factor receptor (PDGFR) are well-known protein tyrosine kinase receptors at the Ras signal pathway. For the Ras signal to be activated, the ligand binds the EGF receptor, followed by induces oligomerization of the receptor [20]. This can allow activation of the kinase activity and transphosphorylation of catalytic domains [20]. The sequence homology 2 (SH2) domain of the receptor is a recognized adaptor protein such as growth factor receptor-bound protein 2 (Grb2), which in turn recruits guanine nucleotide exchange factors (GEFs) like son of sevenless homolog 1 (SOS-1) to the cell membrane [19]. The GEFs are able to interact with Ras protein to promote a conformational change and exchange GDP for GTP. After activation of Ras protein, various downstream effectors such as canonical Raf/Mek/Erk, phosphatidylinositol 3-kinase (PI3K) /3-phosphoinositide-dependent protein kinase-1 (Pdk1)/Akt, and Ral-GEF are recruited (Figure 4$)[5,21]$.

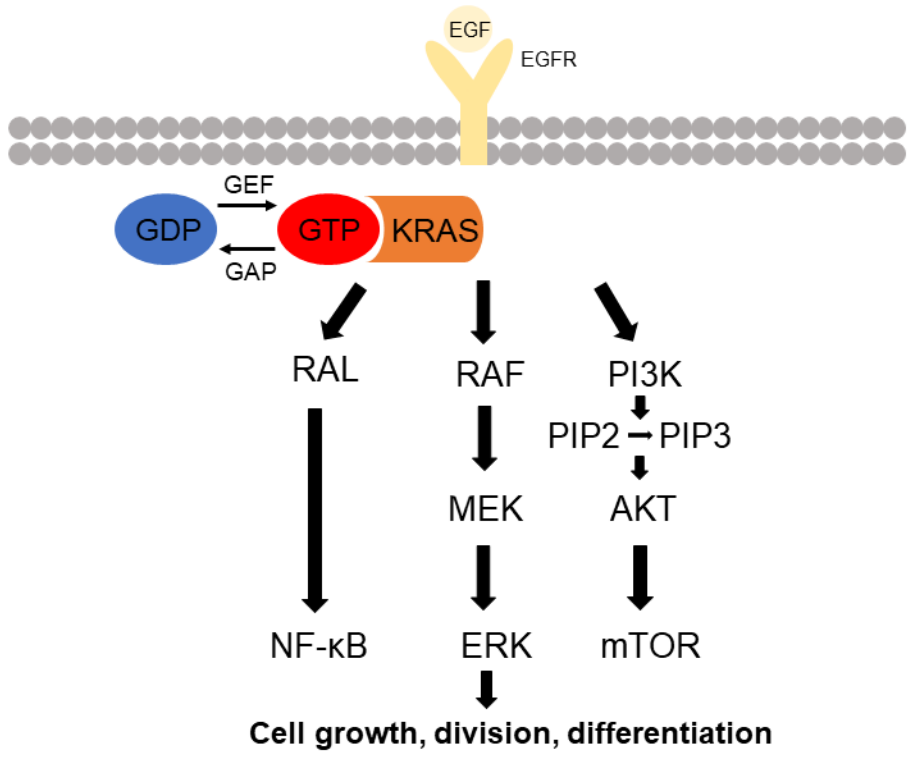

Figure 4. Signaling pathway of KRAS protein. Activation of RAS occurs when epidermal growth factor (EGF) binds to tyrosine kinases receptor such as epidermal growth factor receptor (EGFR). KRAS protein is activated by binding to GTP, transducing the cytoplasmic signal, which activates the RAL, RAF-MEK-ERK, and PI3K-AKT cascade. These cascades regulate cell growth, division, and differentiation.

\subsection{RAF-MEK-ERK Pathway}

The first well-known Ras effector pathway is identified as the RAF-MEK-ERK pathway. This pathway is involved in the mitogenic signaling of tyrosine kinase receptors, following a wide range of growth, differentiation, inflammation, and apoptosis [22]. Raf is a member of the family of serine/tyrosine kinase. Serine/tyrosine kinase includes Raf-1, A-Raf, and B-Raf [19]. This family binds to the effector region of RAS-GTP, resulting in translocation of the Raf protein to the plasma membrane [23,24]. According to the research, Ras activated either by point mutation (G12V) or by GTP-bound interacts with Raf-1 through guanylylimidodiphosphate (GMP-PNP). However, effector domain mutation (Ile36Ala) of Ras does 
not interact with Raf-1 [25]. Following Ras interacting with Raf, Raf protein is activated and phosphorylated by protein kinase. Raf activation induces a signaling cascade, which phosphorylates mitogen-activated protein kinase (MAPK), which in turn, phosphorylates and activates the downstream effector such as extracellular signal-regulated kinase 1 and 2 (ERK1 and ERK2) [19]. Activation of ERK kinases plays a role in Ras-induced cellular responses and translocation to the nucleus [21]. Therefore, ERK activates and phosphorylates the nuclear transcription factor and kinases such as eukaryotic initiation factor 2alpha kinase 1 (EIK-1) and protein C-ets-1,2 (c-Ets1, c-Ets2) [19]. Besides activation of ERK, MAPK, also called MEK, is activated in signal response that promotes cell survival and apoptosis through various mediators such as c-Jun N-terminal kinases (JNK), stressactivated protein kinase (SAPK), and nuclear factor kappa-light-chain-enhancer of activated B cells (NF-KB) [26].

In cancer, studies targeting Raf kinase have been demonstrated. According to the research for the influence of RAF-MEK-ERK pathway in tumor growth, expressing dominantnegative MEK in tumor cells affects a reduction in endogenous Raf-1 and MEK-1 activity [27]. Moreover, research demonstrated that clones expressing the dominant-negative MEK form the smallest tumors and appear to increase survival [27]. Phosphorylation of MEK occurs in residue serine 218 and 222, but MEK point mutation in which these serines are substituted by alanine (S218A/S222A) is not able to be activated Raf [28]. Additionally, inhibition of the RAF-MEK-ERK pathway via mutant MEK demonstrates reversion of the cancer phenotype, and inhibitors of Raf kinase are targeted anti-tumor therapies [29].

\subsection{PI3K Pathway}

The second well-known Ras effector family is phosphoinositide 3-kinases (PI3Ks). PI3K plays a role in mediators of Ras-mediated cell survival and proliferation [30]. Activation of PI3K converts phosphatidylinositol $(4,5)$-biphosphate $\left(\mathrm{PIP}_{2}\right)$ into phosphatidylinositol $(3,4,5)$-triphosphate $\left(\mathrm{PIP}_{3}\right) . \mathrm{PIP}_{3}$, in turn, binds the pleckstrin homology $(\mathrm{PH})$ domain of Akt/PKB. Akt/PKB stimulates phosphorylation of proteins that affect cell growth, cell cycle, and survival [21]. To activate PI3K, binding of a ligand to receptor tyrosine kinase (RTK) first occurs. Following binding of the ligand in RTK, RTK is dimerized and autophosphorylated, leading to interaction with PI3K effector via Src homology 2 (SH2) domains [31]. Adaptor protein of PI3K, GRB2 binds to phosphor-YXN motifs of the RTK. In turn, GRB2 binds and activates SOS, which then activates RAS. Activation of RAS activates p110 of p85 [32]. The tumor suppressor phosphatase and tensing homology (PTEN) dephosphorylates $\mathrm{PIP}_{3}$ to $\mathrm{PIP}_{2}$. $\mathrm{PIP}_{3}$ induces intracellular signaling via binding to protein with PH domains, such as phosphoinositide-dependent kinase (PDK1) and AKT [33]. The PI3K-AKT pathway promotes cell growth and survival $[21,34]$.

The importance of PI3K in the RAS-signaling pathway is highly correlated with oncogenic signaling. According to the research, there is evidence that studies have found somatic missense mutations in PIK3CA in human tumors, including those of the brain, breast, and colon [35-37].

\subsection{Ral-GEF Protein}

The Ral-GEF protein also became known as the Ras effector. Ral-GEF members are composed of RalGDS, RGL, RGL2, and RGL3 [38]. The members are activated the RalA and RalB small GTPase via the link with Ras proteins. Thus, the RalGEF protein is a small GTPase that provides GTP to the Ras superfamily. According to the research, GTPbound RalA and RalB are discovered to have high levels in human pancreatic ductal adenocarcinoma (PDAC). Moreover, inhibition of RalA expression reduces tumorigenic growth [39].

\section{RAS Inhibitors and Resistance}

Acquired resistance occurs for several reasons. Pre-existing and de novo mutations provide chemoresistance and acquired resistance [40]. Resistance mechanisms happen in a 
very rare subpopulation of cells, such as cancer stem cells [41,42]. Kumar, B. et al. revealed that enhanced autophagy induces cancer cell stemness and promotes resistance to colorectal cancer therapy. Moreover, 36-077 promotes the efficacy of colorectal cancer therapy. 36-077 inhibits phosphatidylinositol 3-kinase (PIK3C3/VPS34 kinase) signaling, a key regulator of autophagy, and a potent target for inhibiting autophagy [43]. Long noncoding RNA (lncRNA) is highly expressed in cancer stem cells. lncRNA HAND2-AS1 is required for self-renewal of cancer stem cells, through activation of the bone morphogenetic protein (BMP) signaling [44,45]. Taken together, many pathways and associated factors play a key role in mediating drug resistance.

\subsection{Inhibiting the Post-Translation Processing of RAS}

RAS gene encodes three genes, including HRAS, NRAS, and KRAS. KRAS has two alternatively spliced mRNA variants, KRAS4A and KRAS4B [46]. These proteins with amino-terminal residues 1-165 share 92 98\% sequence identity [47]. RAS proteins carry 23 24 carboxyl-terminal residues, including the CAAX box. CAAX box undergoes fourstage post-translational lipid modification: (1) farnesylation by FTase, (2) prenylation at the CAAX cysteine residue followed by proteolytic [42] removal of the terminal -AAX by Rac converting CAXX endopeptidase 1 (RCE1), (3) carboxymethylation of the C-terminal cysteine by isoprenylcysteine carboxyl methyltransferase (ICMT), and (4) palmitoylation of cysteine residues located upstream of the C-terminus of the protein $[48,49]$.

The excision of RCE1 eliminated RAS endoproteolytic processing and mislocalization of RAS proteins. Moreover, the loss of RCE1 significantly reduces the growth of cells in the skin carcinoma cell line [50]. Treatment of cysmethynil, ICMT inhibitor, results in mislocalization of RAS and inhibition of cell growth and KRAS-induced oncogenic transformation in nude mice [51] (Table 1). TLN-4601 has been shown to disrupt RAS membrane anchorage and anti-tumor activity in several xenograft models. Interestingly, the compound induces Raf-1 proteasomal-dependent degradation and may inhibit the MEK/EKR pathway by depleting the Raf-1 protein [52]. Liu et al. demonstrated that inhibitors of FTase and geranylgeranyltransferase-I were shown to reduce tumor growth and improved survival in mice with K-RAS-induced lung cancer [53]. Waldmann and colleagues targeted the small-molecule inhibitor deltarasin that interferes with the binding of mammalian phosphodiesterase $\delta(\mathrm{PDE} \delta)$ to KRAS and suppresses KRAS localization to endomembrane [54].

Table 1. Summary of therapeutic strategies towards RAS-driven cancer.

\begin{tabular}{|c|c|c|c|c|}
\hline Category & Name & Target & Mode of Inhibition & Ref. \\
\hline \multirow{3}{*}{$\begin{array}{l}\text { Inhibition of } \\
\text { post-translational } \\
\text { processing }\end{array}$} & Cysmethynil & ICMT inhibitor & mislocalization of RAS & [51] \\
\hline & TLN-4601 & MEK/EKR pathway & disrupts RAS membrane anchorage & [52] \\
\hline & deltarasin & PDE $\delta$ & $\begin{array}{l}\text { suppresses KRAS localization } \\
\text { to endomembrane }\end{array}$ & [54] \\
\hline \multirow{6}{*}{$\begin{array}{l}\text { K-RAS targeted } \\
\text { drug }\end{array}$} & ARS-583 & KRAS G12C & inhibits downstream MAPK/PI3K signaling & [55] \\
\hline & ARS-1620 & KRAS G12C & $\begin{array}{l}\text { anti-tumor activity in subcutaneous } \\
\text { xenograft models }\end{array}$ & [56] \\
\hline & AMG 510 & KRAS G12C & $\begin{array}{l}\text { induces pro-inflammatory tumor } \\
\text { microenvironment }\end{array}$ & [57] \\
\hline & MRTX849 & KRAS G12C & $\begin{array}{l}\text { tumor regression in KRAS G12C positive } \\
\text { cell lines }\end{array}$ & [58] \\
\hline & BI-3406 & $\begin{array}{l}\text { KRAS-mutant of G12 } \\
\text { and G13 }\end{array}$ & $\begin{array}{c}\text { interacts with the catalytic domain of SOS, } \\
\text { resulting in interference with the interaction } \\
\text { with KRAS }\end{array}$ & [59] \\
\hline & $\begin{array}{l}\text { ponatinib and } \\
\text { AMG-47a }\end{array}$ & KRAS G12V & reduces the levels of KRAS G12V proteins & [60] \\
\hline
\end{tabular}


Table 1. Cont.

\begin{tabular}{|c|c|c|c|c|}
\hline Category & Name & Target & Mode of Inhibition & Ref. \\
\hline \multirow{3}{*}{$\begin{array}{l}\text { Inhibition of RAS } \\
\text { signaling } \\
\text { networks }\end{array}$} & $\begin{array}{l}\text { WZ4002 and MEK } \\
\text { inhibitor }\end{array}$ & EGFR and MEK & $\begin{array}{c}\text { effective strategy of drug-resistant cancers } \\
\text { and prevents the emergence of } \\
\text { drug-resistant clones }\end{array}$ & {$[61]$} \\
\hline & $\begin{array}{l}\text { gefitinib and Src } \\
\text { inhibitor }\end{array}$ & EGFR and Src & $\begin{array}{l}\text { potent strategy to overcome Src-mediated } \\
\text { ERK reactivation }\end{array}$ & {$[62]$} \\
\hline & $\begin{array}{l}\text { gilteritinib, crenolanib, } \\
\text { and midostaurin }\end{array}$ & FLT3 inhibitor & $\begin{array}{l}\text { designed to have a high affinity for the } \\
\text { ATP-binding region of the active } \\
\text { conformation of FLT3 }\end{array}$ & [63-65] \\
\hline \multirow{4}{*}{$\begin{array}{l}\text { Discovered by } \\
\text { virtual screening }\end{array}$} & BAY-293 & $\begin{array}{l}\text { KRAS-SOS1 } \\
\text { interaction }\end{array}$ & $\begin{array}{l}\text { suppresses the RAS-RAF-MEK-ERK pathway } \\
\text { and inhibits the activation of RAS in } \\
\text { tumor cells }\end{array}$ & {$[66]$} \\
\hline & $\begin{array}{l}\text { tetrahydro } \\
\text { pyridopyrimidines }\end{array}$ & KRAS G12C & locks KRAS in its inactive GDP-bound form & [67] \\
\hline & C19 & KRAS4B-PDE $\delta$ & $\begin{array}{l}\text { suppresses the viability and proliferation of } \\
\text { colorectal cancer cells }\end{array}$ & [68] \\
\hline & D14 and C22 & KRAS4B-PDE $\delta$ & $\begin{array}{l}\text { decreases RAS-GTP activity and ERK and } \\
\text { AKT pathways in pancreatic cancer cells }\end{array}$ & [69] \\
\hline \multirow[b]{2}{*}{ Other inhibitors } & H-REV 107 peptide & KRAS G12V & blocks the activation function of KRAS & [70] \\
\hline & $\begin{array}{l}\text { cisplatin, carboplatin, } \\
\text { and oxaliplatin }\end{array}$ & & widely used to treat several cancers & [71] \\
\hline
\end{tabular}

ICMT: isoprenylcysteine carboxyl methyltransferase, MEK: mitogen-activated protein kinase, ERK: extracellular signal-regulated kinase, PDE $\delta$ : phosphodiesterase $\delta$, EGFR: epidermal growth factor receptor, FLT3: FMS-like receptor tyrosine kinase-3.

\subsection{K-RAS Targeted Drug}

The most mutation sites of oncogenic mutation in RAS are residues 12 and 13 in the P-loop, and residue 61 in switch II [72]. KRAS, which is most frequently mutated, contains $86 \%$ of RAS mutation. KRAS mutations occur in pancreatic, colorectal, and lung cancers. The vast majority of hotspot positions are on 12 . NRAS mutations occur in melanoma and myeloid leukemia, with the most common site of mutation being residue 61 . HRAS mutations occur with the highest frequency in bladder cancer, and hotspots are 12 and 61 residues [73] (Table 2).

Table 2. Frequency of RAS isoform mutations in human cancer. Table shows the distribution of mutations in the various primary tissue types. Data are from the COSMIC database. Numbers in parentheses indicate sequence of total tested sample.

\begin{tabular}{cccc}
\hline Primary Tissue & NRAS $(\%)$ & KRAS $(\%)$ & HRAS (\%) \\
\hline pancreas & $0.77(4016)$ & $52.65(13,817)$ & $0.11(3542)$ \\
\hline colon & $3.87(16,337)$ & $32.37(80,177)$ & $0.94(6095)$ \\
\hline small intestine & $0.45(443)$ & $21.34(1256)$ & $0.3(336)$ \\
\hline lung & $0.91(17,505)$ & $14.19(45,776)$ & $0.6(7890)$ \\
\hline ovary & $1.71(1932)$ & $13.03(6932)$ & $0.24(1693)$ \\
\hline liver & $1.07(3174)$ & $3.15(3614)$ & $0.24(2912)$ \\
\hline kidney & $0.34(3498)$ & $0.93(4423)$ & $0.25(3265)$ \\
\hline skin & $15.36(15,960)$ & $2.8(6833)$ & $9.42(7067)$ \\
\hline endometrium & $3.22(1648)$ & $15.45(4674)$ & $0.58(2395)$ \\
\hline biliary tract & $2.7(2256)$ & $18.05(5518)$ & $0.56(1794)$ \\
\hline
\end{tabular}


ARS-583 reacts with the GDP-bound state of KRAS G12C. ARS-583 inhibits downstream MAPK/PI3K signaling across the group of cell lines and directly inhibits the treatment of patients with the KRAS G12C mutation, which comprises $20 \%$ of lung cancers [55]. ARS-1620 selectively and with high potency targets the switch II pocket in KRAS G12C. ARS-1620 achieves anti-tumor activity in subcutaneous xenograft models bearing KRAS G12C mutation [56]. Ryan et al. observed rapid adaptive RAS pathway feedback reactivation of MAPK signaling after treatment with ARS-1620 in KRAS G12C-driven lung, pancreatic, and colon cancer cells, suggesting secondary resistance via upregulated RTK signaling [74]. Treatment with AMG 510 regresses in KRAS G12C mouse xenografts and induces pro-inflammatory tumor microenvironment [57]. A covalent KRAS G12C inhibitor, MRTX849, selectively modifies mutant cysteine 12 in a GDP-bound state. MRTX849 has tumor regression in KRAS G12C positive cell lines and patient-derived xenograft models from multiple tumor types [58]. Small-molecule SOS1 inhibitor, BI-3406, interacts with the catalytic domain of SOS, resulting in interference with the interaction with KRAS and thereby restricting tumor cell proliferation in KRAS-mutant cancer, including G12 and G13 [59]. BI 1701963, which is a BI-3406 analog, is currently in a phase I trial, testing preliminary efficacy of BI 1701963 alone and in combination with trametinib in patients with KRAS mutant solid tumors [75]. Compounds of ponatinib and AMG-47a selectively reduce the levels of KRAS G12V proteins [60].

\subsection{Inhibition of RAS Signaling Networks}

Upstream RAS-mediated pathways have a common mechanism of resistance to tyrosine kinase inhibitors (TKIs) such as those targeting RTKs, including EGFR and FMS-like receptor tyrosine kinase-3 (FLT3) [40]. Treatment with anti-EGFR monoclonal antibodies cetuximab or panitumumab is successful in a subset of patients with colorectal cancer, although these stimulate MAPK reactivation, driving secondary resistance [76]. Resistance to EGFR inhibitor WZ4002 can induce reactivation of ERK1/2 signaling. Ercan et al. found that the combination of WZ4002 and MEK inhibitor may be an effective strategy to treat drug-resistant cancers [61]. EGFR inhibitor gefitinib showed drug resistance via Srcmediated ERK reactivation. Ochi et al. demonstrated that a combination of gefitinib and Src inhibitor may increase the potency of the RAS-inhibitor resistance mechanism to overcome this resistance [62]. Many different FLT3 inhibitors including gilteritinib, crenolanib, and midostaurin treat varying stages. Gilteritinib and midostaurin are FDA-approved whereas crenolanib is in phase II trials [63-65]. However, gilteritinib develops secondary resistance via activating RAS/MAPK pathway signaling in acute myeloid leukemia, most commonly in NRAS or KRAS [77]. The MRAS-SHOC2-PPI complex acts as a key role in the RAF-ERK pathway. Jones et al. reported that inhibition of SHOC2 inhibits tumor development in murine KRAS-driven lung cancer models. However, this compound activates other RAS-dependent pathways such as PI3K-AKT signaling, resulting in cancer that can persist [40,78]. Adachi and colleagues observed that epithelial-to-mesenchymal transition (EMT) led to intrinsic and acquired resistance by activation of PI3K signaling in the presence of KRAS G12C inhibitor. Treatment with the combination of KRAS G12C inhibitor, PI3K inhibitor, and SHP2 inhibitor resulted in tumor regression in mouse models of acquired resistance to KRAS G12C inhibitor, AMG510 [79].

\subsection{KRAS Inhibitors Discovered by Virtual Screening}

Covalent quinazoline-based switch II compounds effectively inhibit GTP loading of KRAS G12V, MAPK phosphorylation, and the growth of cancer cells driven by KRAS G12C [80]. Compound 23 (BAY-293) selectively inhibits the KRAS-SOS1 interaction and blocks reloading of KRAS with GTP. The compound suppresses the RAS-RAF-MEK-ERK pathway and inhibits the activation of RAS in tumor cells [66]. Fell et al. reported that tetrahydro pyridopyrimidines act as irreversible covalent inhibitors of KRAS G12C and can bind to the residue 12 and lock KRAS in its inactive GDP-bound form [67]. C19 bound and stabilized the KRAS4B-PDE $\delta$ complex. This compound suppresses the viability and 
proliferation of colorectal cancer cells and decreases tumor size in a xenograft mouse model via inhibiting phosphorylation of ERK and AKT signaling [68]. In addition, D14 and C22 stabilize the interaction with KRAS4B and PDE $\delta$. D14 and C22 significantly decrease RAS-GTP activity and ERK and AKT pathways in pancreatic cancer cells [69].

\subsection{Other Inhibitors Targeting RAS}

CW Han et al. elucidated that there is direct interaction between KRAS G12V and H-REV 107 peptide with high affinity with the crystal structure. This peptide was shown to interact and stabilize with KRAS G12V inactive state resulting in the block of the activation function of KRAS. The peptide can inhibit pancreatic cancer and colon cancer cell lines in cell proliferation assay [70]. Treatment with platinum-based agents, such as cisplatin, carboplatin, and oxaliplatin, is used in a variety of cancers, including head and neck squamous cell carcinoma, testicular cancer, and non-small cell lung cancer [71,81,82]. Cisplatin induces mitochondrial ROS, which further increases DNA damage and induces increasing cell death. However, cisplatin shows an observed resistance mechanism, including the involvement of oncogenic KRAS mutations via NRF2 overexpressing [71].

\section{Conclusions}

RAS proteins are membrane-bound proteins and are frequently mutated in human cancers, with mutations in about $30 \%$ of all cancers. RAS exists in three ubiquitously expressed genes, HRAS, KRAS, and NRAS, with high sequence homology. RAS proteins cycle between an inactive (GDP-bound) and active (GTP-bound) state. When activated by a ligand-bound RTK such as EGFR and FLT3, RAS triggers diverse signaling cascades, including PI3K and MAPK/ERK signaling, to induce cell growth, differentiation, and survival. Oncogenic mutations of RAS in several upstream or downstream pathways occur in most tumors, indicating that inhibition of RAS-dependent signaling is the essential requirement for tumorigenesis. While RAS proteins have been seen as an attractive target for cancer therapy, continuous efforts to inhibit RAS either directly or indirectly through inhibiting post-translational modification or RAS-dependent signaling to date have failed to develop approved therapies for RAS mutant cancer. Previous failures of RAS-targeting treatments, including farnesyltransferase inhibitors, have resulted in RAS being generally considered undruggable. Additionally, because of the high picomolar affinity between RAS and GTP, a competitive inhibitor is not expressly possible. However, the discovery of the structure of RAS has given an understanding of the key residues with new promising compounds. Despite evidence supporting the cancer stem cell theory, resistance to inhibition of RAS appears to be diverse. Durable response to these treatments is yet to be achieved due to complex and diverse mechanisms of adaptive resistance. However, it is expected that employing this rationale will lead to better treatments and a better outcome for patients.

Author Contributions: H.J.K. and H.N.L. wrote the manuscript. M.S.J. and S.B.J. designed and provided analysis of the manuscript. All authors have read and agreed to the published version of the manuscript.

Funding: This research was funded by MEST (2018R1D1A1B07043701) for S.B.J. and (2016R1D1A1 B02011142) for M.S.J.

Acknowledgments: This study was supported by the Basic Science Research Program through the National Research Foundation of Korea (NRF) funded by the Ministry of Education, Science and Technology (2018R1D1A1B07043701) for S.B.J. and (2016R1D1A1B02011142) for M.S.J.

Conflicts of Interest: The authors declare no conflict of interest.

\section{References}

1. Wennerberg, K.; Rossman, K.L.; Der, C.J. The Ras superfamily at a glance. J. Cell Sci. 2005, 118, 843-846. [CrossRef]

2. Jančík, S.; Drábek, J.; Radzioch, D.; Hajdúch, M. Clinical relevance of KRAS in human cancers. J. Biomed. Biotechnol. 2010, 2010, 150960. [CrossRef] 
3. Merrick, B.A.; Phadke, D.P.; Bostrom, M.A.; Shah, R.R.; Wright, G.M.; Wang, X.; Gordon, O.; Pelch, K.E.; Auerbach, S.S.; Paules, R.S. Arsenite malignantly transforms human prostate epithelial cells in vitro by gene amplification of mutated KRAS. PLoS ONE 2019, 14, e0215504. [CrossRef] [PubMed]

4. McGrath, J.P.; Capon, D.J.; Smith, D.H.; Chen, E.Y.; Seeburg, P.H.; Goeddel, D.V.; Levinson, A.D. Structure and organization of the human Ki-ras proto-oncogene and a related processed pseudogene. Nature 1983, 304, 501-506. [CrossRef] [PubMed]

5. Pylayeva-Gupta, Y.; Grabocka, E.; Bar-Sagi, D. RAS oncogenes: Weaving a tumorigenic web. Nat. Rev. Cancer 2011, 11, 761-774. [CrossRef] [PubMed]

6. Gideon, P.; John, J.; Frech, M.; Lautwein, A.; Clark, R.; Scheffler, J.E.; Wittinghofer, A. Mutational and kinetic analyses of the GTPase-activating protein (GAP)-p21 interaction: The C-terminal domain of GAP is not sufficient for full activity. Mol. Cell. Biol. 1992, 12, 2050-2056. [CrossRef] [PubMed]

7. Simanshu, D.K.; Nissley, D.V.; McCormick, F. RAS proteins and their regulators in human disease. Cell 2017, 170, 17-33. [CrossRef]

8. Hodge, R.G.; Schaefer, A.; Howard, S.V.; Der, C.J. RAS and RHO family GTPase mutations in cancer: Twin sons of different mothers? Crit. Rev. Biochem. Mol. Biol. 2020, 55, 386-407. [CrossRef]

9. Pantsar, T. The current understanding of KRAS protein structure and dynamics. Comput. Struct. Biotechnol. J. 2020, 18, 189-198. [CrossRef]

10. Ahearn, I.; Zhou, M.; Philips, M.R. Posttranslational modifications of RAS proteins. Cold Spring Harb. Perspect. Med. 2018, 8, a031484. [CrossRef]

11. Choy, E.; Chiu, V.K.; Silletti, J.; Feoktistov, M.; Morimoto, T.; Michaelson, D.; Ivanov, I.E.; Philips, M.R. Endomembrane trafficking of ras: The CAAX motif targets proteins to the ER and Golgi. Cell 1999, 98, 69-80. [CrossRef]

12. Abraham, S.J.; Muhamed, I.; Nolet, R.; Yeung, F.; Gaponenko, V. Expression, purification, and characterization of soluble K-Ras4B for structural analysis. Protein Expr. Purif. 2010, 73, 125-131. [CrossRef]

13. Mo, S.P.; Coulson, J.M.; Prior, I.A. RAS variant signalling. Biochem. Soc. Trans. 2018, 46, 1325. [CrossRef]

14. Parker, J.A.; Mattos, C. The K-Ras, N-Ras, and H-Ras isoforms: Unique conformational preferences and implications for targeting oncogenic mutants. Cold Spring Harb. Perspect. Med. 2018, 8, a031427. [CrossRef]

15. Hancock, J.F.; Magee, A.I.; Childs, J.E.; Marshall, C.J. All ras proteins are polyisoprenylated but only some are palmitoylated. Cell 1989, 57, 1167-1177. [CrossRef]

16. Aicart-Ramos, C.; Valero, R.A.; Rodriguez-Crespo, I. Protein palmitoylation and subcellular trafficking. Biochim. Biophys. Acta BBA Biomembr. 2011, 1808, 2981-2994. [CrossRef]

17. Thissen, J.A.; Gross, J.M.; Subramanian, K.; Meyer, T.; Casey, P.J. Prenylation-dependent association of Ki-Ras with microtubules: Evidence for a role in subcellular trafficking. J. Biol. Chem. 1997, 272, 30362-30370. [CrossRef] [PubMed]

18. Avruch, J.; Khokhlatchev, A.; Kyriakis, J.M.; Luo, Z.; Tzivion, G.; Vavvas, D.; Zhang, X. Ras activation of the Raf kinase: Tyrosine kinase recruitment of the MAP kinase cascade. Recent Prog. Horm. Res. 2001, 56, 127-155. [CrossRef]

19. Molina, J.R.; Adjei, A.A. The ras/raf/mapk pathway. J. Thorac. Oncol. 2006, 1, 7-9. [CrossRef]

20. Lemmon, M.A.; Schlessinger, J. Cell signaling by receptor tyrosine kinases. Cell 2010, 141, 1117-1134. [CrossRef] [PubMed]

21. Castellano, E.; Downward, J. RAS interaction with PI3K: More than just another effector pathway. Genes Cancer 2011, 2, 261-274. [CrossRef]

22. Roux, P.P.; Blenis, J. ERK and p38 MAPK-activated protein kinases: A family of protein kinases with diverse biological functions. Microbiol. Mol. Biol. Rev. 2004, 68, 320-344. [CrossRef] [PubMed]

23. Warne, P.H.; Vician, P.R.; Downward, J. Direct interaction of Ras and the amino-terminal region of Raf-1 in vitro. Nature 1993, 364, 352-355. [CrossRef]

24. Zhang, X.-F.; Settleman, J.; Kyriakis, J.; Takeuchi-Suzuki, E.; Elledge, S.J.; Marshall, M.S.; Bruder, J.T.; Rapp, U.R.; Avruch, J. Normal and oncogenic p21 ras proteins bind to the amino-terminal regulatory domain of c-Raf-1. Nature 1993, 364, 308-313. [CrossRef]

25. Moodie, S.A.; Willumsen, B.M.; Weber, M.J.; Wolfman, A. Complexes of Ras. GTP with Raf-1 and mitogen-activated protein kinase kinase. Science 1993, 260, 1658-1661. [CrossRef]

26. Schlesinger, T.K.; Fanger, G.R.; Yujiri, T.; Johnson, G.L. The tao of MEKK. Front. Biosci 1998, 3, D1181-D1186. [CrossRef]

27. Arboleda, M.J.; Eberwein, D.; Hibner, B.; Lyons, J.F. Dominant negative mutants of mitogen-activated protein kinase pathway. Methods Enzymol. 2001, 332, 353-367. [PubMed]

28. Zheng, C.-F.; Guan, K.-L. Activation of MEK family kinases requires phosphorylation of two conserved Ser/Thr residues. EMBO J. 1994, 13, 1123-1131. [CrossRef]

29. Lyons, J.; Wilhelm, S.; Hibner, B.; Bollag, G. Discovery of a novel Raf kinase inhibitor. Endocr.-Relat. Cancer 2001, 8, 219-225. [CrossRef] [PubMed]

30. Castellano, E.; Downward, J. Role of RAS in the regulation of PI 3-kinase. Phosphoinositide 3-Kinase Health Dis. $2010,1,143-169$.

31. Schlessinger, J. Ligand-induced, receptor-mediated dimerization and activation of EGF receptor. Cell 2002, 110, 669-672. [CrossRef]

32. Pawson, T. Specificity in signal transduction: From phosphotyrosine-SH2 domain interactions to complex cellular systems. Cell 2004, 116, 191-203. [CrossRef]

33. Liu, P.; Cheng, H.; Roberts, T.M.; Zhao, J.J. Targeting the phosphoinositide 3-kinase pathway in cancer. Nat. Rev. Drug Discov. 2009, 8, 627-644. [CrossRef] 
34. Cantley, L.C. The phosphoinositide 3-kinase pathway. Science 2002, 296, 1655-1657. [CrossRef] [PubMed]

35. Samuels, Y.; Wang, Z.; Bardelli, A.; Silliman, N.; Ptak, J.; Szabo, S.; Yan, H.; Gazdar, A.; Powell, S.M.; Riggins, G.J. High frequency of mutations of the PIK3CA gene in human cancers. Science 2004, 304, 554. [CrossRef]

36. Thomas, R.K.; Baker, A.C.; DeBiasi, R.M.; Winckler, W.; LaFramboise, T.; Lin, W.M.; Wang, M.; Feng, W.; Zander, T.; MacConaill, L.E. High-throughput oncogene mutation profiling in human cancer. Nat. Genet. 2007, 39, 347-351. [CrossRef] [PubMed]

37. Simi, L.; Pratesi, N.; Vignoli, M.; Sestini, R.; Cianchi, F.; Valanzano, R.; Nobili, S.; Mini, E.; Pazzagli, M.; Orlando, C. Highresolution melting analysis for rapid detection of KRAS, BRAF, and PIK3CA gene mutations in colorectal cancer. Am. J. Clin. Pathol. 2008, 130, 247-253. [CrossRef]

38. D'Adamo, D.R.; Novick, S.; Kahn, J.M.; Leonardi, P.; Pellicer, A. rsc: A novel oncogene with structural and functional homology with the gene family of exchange factors for Ral. Oncogene 1997, 14, 1295-1305. [CrossRef]

39. Lim, K.-H.; O'Hayer, K.; Adam, S.J.; Kendall, S.D.; Campbell, P.M.; Der, C.J.; Counter, C.M. Divergent roles for RalA and RalB in malignant growth of human pancreatic carcinoma cells. Curr. Biol. 2006, 16, 2385-2394. [CrossRef]

40. Healy, F.M.; Prior, I.A.; MacEwan, D.J. The importance of Ras in drug resistance in cancer. Br. J. Pharmacol. 2021. [CrossRef]

41. Najafi, M.; Mortezaee, K.; Majidpoor, J. Cancer stem cell (CSC) resistance drivers. Life Sci. 2019, 234, 116781. [CrossRef] [PubMed]

42. Lytle, N.K.; Barber, A.G.; Reya, T. Stem cell fate in cancer growth, progression and therapy resistance. Nat. Rev. Cancer 2018, 18, 669-680. [CrossRef]

43. Kumar, B.; Ahmad, R.; Sharma, S.; Gowrikumar, S.; Primeaux, M.; Rana, S.; Natarajan, A.; Oupicky, D.; Hopkins, C.R.; Dhawan, P. PIK3C3 Inhibition Promotes Sensitivity to Colon Cancer Therapy by Inhibiting Cancer Stem Cells. Cancers 2021, $13,2168$. [CrossRef]

44. Wang, Y.; Zhu, P.; Luo, J.; Wang, J.; Liu, Z.; Wu, W.; Du, Y.; Ye, B.; Wang, D.; He, L. LncRNA HAND2-AS1 promotes liver cancer stem cell self-renewal via BMP signaling. EMBO J. 2019, 38, e101110. [CrossRef] [PubMed]

45. Zhou, J.; Lin, J.; Zhang, H.; Zhu, F.; Xie, R. LncRNA HAND2-AS1 sponging miR-1275 suppresses colorectal cancer progression by upregulating KLF14. Biochem. Biophys. Res. Commun. 2018, 503, 1848-1853. [CrossRef] [PubMed]

46. Zhou, B.; Der, C.J.; Cox, A.D. The Role of Wild Type RAS Isoforms in Cancer; Seminars in Cell \& Developmental Biology; Elsevier: Amsterdam, The Netherlands, 2016; pp. 60-69.

47. Casey, P.J.; Solski, P.A.; Der, C.J.; Buss, J.E. p21ras is modified by a farnesyl isoprenoid. Proc. Natl. Acad. Sci. USA 1989, 86, 8323-8327. [CrossRef] [PubMed]

48. Wang, Y.; Kaiser, C.E.; Frett, B.; Li, H.-y. Targeting mutant KRAS for anticancer therapeutics: A review of novel small molecule modulators. J. Med. Chem. 2013, 56, 5219-5230. [CrossRef] [PubMed]

49. Friday, B.B.; Adjei, A.A. K-ras as a target for cancer therapy. Biochim. Biophys. Acta BBA Rev. Cancer 2005, 1756, 127-144. [CrossRef]

50. Bergo, M.O.; Ambroziak, P.; Gregory, C.; George, A.; Otto, J.C.; Kim, E.; Nagase, H.; Casey, P.J.; Balmain, A.; Young, S.G. Absence of the CAAX endoprotease Rce1: Effects on cell growth and transformation. Mol. Cell. Biol. 2002, 22, 171-181. [CrossRef] [PubMed]

51. Winter-Vann, A.M.; Baron, R.A.; Wong, W.; dela Cruz, J.; York, J.D.; Gooden, D.M.; Bergo, M.O.; Young, S.G.; Toone, E.J.; Casey, P.J. A small-molecule inhibitor of isoprenylcysteine carboxyl methyltransferase with antitumor activity in cancer cells. Proc. Natl. Acad. Sci. USA 2005, 102, 4336-4341. [CrossRef]

52. Boufaied, N.; Wioland, M.-A.; Falardeau, P.; Gourdeau, H. TLN-4601, a novel anticancer agent, inhibits Ras signaling post Ras prenylation and before MEK activation. Anti-Cancer Drugs 2010, 21, 543-552. [CrossRef]

53. Liu, M.; Sjogren, A.-K.M.; Karlsson, C.; Ibrahim, M.X.; Andersson, K.M.; Olofsson, F.J.; Wahlstrom, A.M.; Dalin, M.; Yu, H.; Chen, $\mathrm{Z}$. Targeting the protein prenyltransferases efficiently reduces tumor development in mice with K-RAS-induced lung cancer. Proc. Natl. Acad. Sci. USA 2010, 107, 6471-6476. [CrossRef] [PubMed]

54. Zimmermann, G.; Papke, B.; Ismail, S.; Vartak, N.; Chandra, A.; Hoffmann, M.; Hahn, S.A.; Triola, G.; Wittinghofer, A.; Bastiaens, P.I. Small molecule inhibition of the KRAS-PDE $\delta$ interaction impairs oncogenic KRAS signalling. Nature 2013, 497, 638-642. [CrossRef]

55. Patricelli, M.P.; Janes, M.R.; Li, L.-S.; Hansen, R.; Peters, U.; Kessler, L.V.; Chen, Y.; Kucharski, J.M.; Feng, J.; Ely, T. Selective inhibition of oncogenic KRAS output with small molecules targeting the inactive state. Cancer Discov. 2016, 6, 316-329. [CrossRef] [PubMed]

56. Janes, M.R.; Zhang, J.; Li, L.-S.; Hansen, R.; Peters, U.; Guo, X.; Chen, Y.; Babbar, A.; Firdaus, S.J.; Darjania, L. Targeting KRAS mutant cancers with a covalent G12C-specific inhibitor. Cell 2018, 172, 578-589.e17. [CrossRef]

57. Canon, J.; Rex, K.; Saiki, A.Y.; Mohr, C.; Cooke, K.; Bagal, D.; Gaida, K.; Holt, T.; Knutson, C.G.; Koppada, N. The clinical KRAS (G12C) inhibitor AMG 510 drives anti-tumour immunity. Nature 2019, 575, 217-223. [CrossRef] [PubMed]

58. Hallin, J.; Engstrom, L.D.; Hargis, L.; Calinisan, A.; Aranda, R.; Briere, D.M.; Sudhakar, N.; Bowcut, V.; Baer, B.R.; Ballard, J.A. The KRASG12C inhibitor MRTX849 provides insight toward therapeutic susceptibility of KRAS-mutant cancers in mouse models and patients. Cancer Discov. 2020, 10, 54-71. [CrossRef] [PubMed]

59. Hofmann, M.H.; Gmachl, M.; Ramharter, J.; Savarese, F.; Gerlach, D.; Marszalek, J.R.; Sanderson, M.P.; Kessler, D.; Trapani, F.; Arnhof, H. BI-3406, a potent and selective SOS1-KRAS interaction inhibitor, is effective in KRAS-driven cancers through combined MEK inhibition. Cancer Discov. 2021, 11, 142-157. [CrossRef]

60. Carver, J.; Dexheimer, T.S.; Hsu, D.; Weng, M.-T.; Smith, J.L.; Guha, R.; Jadhav, A.; Simeonov, A.; Luo, J. A high-throughput assay for small molecule destabilizers of the KRAS oncoprotein. PLoS ONE 2014, 9, e103836. [CrossRef] 
61. Ercan, D.; Xu, C.; Yanagita, M.; Monast, C.S.; Pratilas, C.A.; Montero, J.; Butaney, M.; Shimamura, T.; Sholl, L.; Ivanova, E.V. Reactivation of ERK signaling causes resistance to EGFR kinase inhibitors. Cancer Discov. 2012, 2, 934-947. [CrossRef]

62. Ochi, N.; Takigawa, N.; Harada, D.; Yasugi, M.; Ichihara, E.; Hotta, K.; Tabata, M.; Tanimoto, M.; Kiura, K. Src mediates ERK reactivation in gefitinib resistance in non-small cell lung cancer. Exp. Cell Res. 2014, 322, 168-177. [CrossRef] [PubMed]

63. Galanis, A.; Ma, H.; Rajkhowa, T.; Ramachandran, A.; Small, D.; Cortes, J.; Levis, M. Crenolanib is a potent inhibitor of FLT3 with activity against resistance-conferring point mutants. Blood J. Am. Soc. Hematol. 2014, 123, 94-100. [CrossRef] [PubMed]

64. Levis, M. Midostaurin approved for FLT3-mutated AML. Blood J. Am. Soc. Hematol. 2017, 129, 3403-3406. [CrossRef] [PubMed]

65. Zhang, H.; Savage, S.; Schultz, A.R.; Bottomly, D.; White, L.; Segerdell, E.; Wilmot, B.; McWeeney, S.K.; Eide, C.A.; Nechiporuk, T. Clinical resistance to crenolanib in acute myeloid leukemia due to diverse molecular mechanisms. Nat. Commun. 2019, 10, 1-13. [CrossRef]

66. Hillig, R.C.; Sautier, B.; Schroeder, J.; Moosmayer, D.; Hilpmann, A.; Stegmann, C.M.; Werbeck, N.D.; Briem, H.; Boemer, U.; Weiske, J. Discovery of potent SOS1 inhibitors that block RAS activation via disruption of the RAS-SOS1 interaction. Proc. Natl. Acad. Sci. USA 2019, 116, 2551-2560. [CrossRef] [PubMed]

67. Fell, J.B.; Fischer, J.P.; Baer, B.R.; Ballard, J.; Blake, J.F.; Bouhana, K.; Brandhuber, B.J.; Briere, D.M.; Burgess, L.E.; Burkard, M.R. Discovery of tetrahydropyridopyrimidines as irreversible covalent inhibitors of KRAS-G12C with in vivo activity. ACS Med. Chem. Lett. 2018, 9, 1230-1234. [CrossRef]

68. Cruz-Nova, P.; Schnoor, M.; Correa-Basurto, J.; Bello, M.; Briseño-Diaz, P.; Rojo-Domínguez, A.; Ortiz-Mendoza, C.M.; GuerreroAguirre, J.; García-Vázquez, F.J.; Hernández-Rivas, R. The small organic molecule C19 binds and strengthens the KRAS4b-PDE $\delta$ complex and inhibits growth of colorectal cancer cells in vitro and in vivo. BMC Cancer 2018, 18, 1-13. [CrossRef]

69. Casique-Aguirre, D.; Briseño-Díaz, P.; García-Gutiérrez, P.; González-de la Rosa, C.H.; Quintero-Barceinas, R.S.; Rojo-Domínguez, A.; Vergara, I.; Medina, L.A.; Correa-Basurto, J.; Bello, M. KRas4B-PDE6 complex stabilization by small molecules obtained by virtual screening affects Ras signaling in pancreatic cancer. BMC Cancer 2018, 18, 1-16. [CrossRef]

70. Han, C.W.; Jeong, M.S.; Ha, S.C.; Jang, S.B. A H-REV107 Peptide Inhibits Tumor Growth and Interacts Directly with Oncogenic KRAS Mutants. Cancers 2020, 12, 1412. [CrossRef]

71. Silva, M.M.; Rocha, C.R.R.; Kinker, G.S.; Pelegrini, A.L.; Menck, C.F.M. The balance between NRF2/GSH antioxidant mediated pathway and DNA repair modulates cisplatin resistance in lung cancer cells. Sci. Rep. 2019, 9, 1-11.

72. Prior, I.A.; Lewis, P.D.; Mattos, C. A comprehensive survey of Ras mutations in cancer. Cancer Res. 2012, 72, 2457-2467. [CrossRef]

73. Ostrem, J.M.; Shokat, K.M. Direct small-molecule inhibitors of KRAS: From structural insights to mechanism-based design. Nat. Rev. Drug Discov. 2016, 15, 771-785. [CrossRef]

74. Ryan, M.B.; de la Cruz, F.F.; Phat, S.; Myers, D.T.; Wong, E.; Shahzade, H.A.; Hong, C.B.; Corcoran, R.B. Vertical pathway inhibition overcomes adaptive feedback resistance to KRASG12C inhibition. Clin. Cancer Res. 2020, 26, 1633-1643. [CrossRef]

75. Gerlach, D.; Gmachl, M.; Ramharter, J.; Teh, J.; Fu, S.-C.; Trapani, F.; Kessler, D.; Rumpel, K.; Botesteanu, D.-A.; Ettmayer, P.; et al. BI-3406 and BI 1701963: Potent and selective SOS1:: KRAS inhibitors induce regressions in combination with MEK inhibi-tors or irinotecan. In Proceedings of the AACR Annual Meeting, Philadelphia, PA, USA, 22-24 June 2020; Volume 80, p. 1091.

76. Pietrantonio, F.; Vernieri, C.; Siravegna, G.; Mennitto, A.; Berenato, R.; Perrone, F.; Gloghini, A.; Tamborini, E.; Lonardi, S.; Morano, F. Heterogeneity of acquired resistance to anti-EGFR monoclonal antibodies in patients with metastatic colorectal cancer. Clin. Cancer Res. 2017, 23, 2414-2422. [CrossRef]

77. McMahon, C.M.; Ferng, T.; Canaani, J.; Wang, E.S.; Morrissette, J.J.; Eastburn, D.J.; Pellegrino, M.; Durruthy-Durruthy, R.; Watt, C.D.; Asthana, S. Clonal selection with RAS pathway activation mediates secondary clinical resistance to selective FLT3 inhibition in acute myeloid leukemia. Cancer Discov. 2019, 9, 1050-1063. [CrossRef]

78. Jones, G.G.; Del Río, I.B.; Sari, S.; Sekerim, A.; Young, L.C.; Hartig, N.; Zubiaur, I.A.; El-Bahrawy, M.A.; Hynds, R.E.; Lei, W. SHOC2 phosphatase-dependent RAF dimerization mediates resistance to MEK inhibition in RAS-mutant cancers. Nat. Commun. 2019, 10, 1-16. [CrossRef]

79. Adachi, Y.; Ito, K.; Hayashi, Y.; Kimura, R.; Tan, T.Z.; Yamaguchi, R.; Ebi, H. Epithelial-to-Mesenchymal Transition is a Cause of Both Intrinsic and Acquired Resistance to KRAS G12C Inhibitor in KRAS G12C-Mutant Non-Small Cell Lung Cancer. Clin. Cancer Res. 2020, 26, 5962-5973. [CrossRef]

80. Zeng, M.; Lu, J.; Li, L.; Feru, F.; Quan, C.; Gero, T.W.; Ficarro, S.B.; Xiong, Y.; Ambrogio, C.; Paranal, R.M. Potent and selective covalent quinazoline inhibitors of KRAS G12C. Cell Chem. Biol. 2017, 24, 1005-1016.e3. [CrossRef]

81. De Vries, G.; Rosas-Plaza, X.; van Vugt, M.A.; Gietema, J.A.; de Jong, S. Testicular cancer: Determinants of cisplatin sensitivity and novel therapeutic opportunities. Cancer Treat. Rev. 2020, 88, 102054. [CrossRef] [PubMed]

82. Weykamp, F.; Seidensaal, K.; Rieken, S.; Green, K.; Mende, S.; Zaoui, K.; Freier, K.; Adeberg, S.; Debus, J.; Welte, S.E. Agedependent hemato-and nephrotoxicity in patients with head and neck cancer receiving chemoradiotherapy with weekly cisplatin. Strahlenther. Onkol. 2020, 196, 515-521. [CrossRef] 